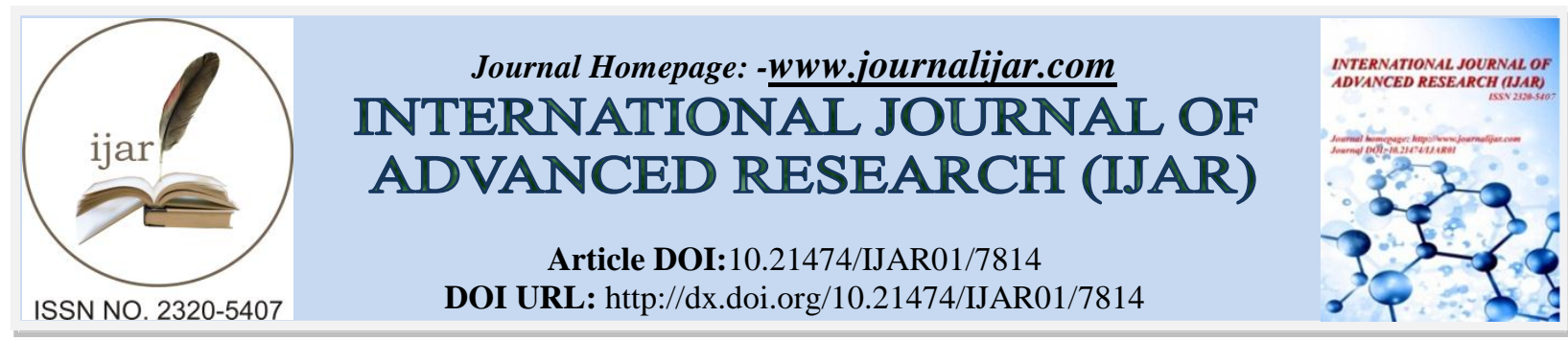

RESEARCH ARTICLE

\title{
LANDED ARISTOCRACY AND EMERGENCE OF SOCIAL STRATIFICATION AMONG MUSLIMS IN CACHAR (1830-1947)
}

Ohi Uddin Ahmed.

Ph.D. Research Scholar Dept. Of History, Assam University, Silchar, Assam.

\section{Manuscript Info}

\section{Manuscript History}

Received: 6 August 2018

Final Accepted: 8 September 2018

Published: October 2018

\begin{abstract}
India has been basically an agrarian country and land revenue was the chief source of income to the rulers. The pre-colonial as well as colonial rulers were much concerned about the smooth collection of revenue, the objective being the maximum collection. The development of different kinds of institution of land led to the emergence of landed gentry during different periods of Indian History. The landed elite class or aristocrats remained the most influential institution in society in terms of political, social and economic dominance. The pre-colonial as well as colonial rulers of Cachar in southern Assam organised land revenue system associated with the emergence of precise landed class both among the Hindus as well as Muslims.

The landed aristocrats being the rich, owning big estate and amassing wealth, remained as a class apart from rest of the society. They maintained matrimonial relationship with their fellow aristocratic class leading to the beginning of endogamous tradition in Muslim society with already existed caste endogamy. This factor resulted in the formation of new trends of towards upward social mobility by the agricultural and other intermediary class of people and resulted in the further proliferation of Muslim social order and formation of class stratification. In course of time, class stratification interacted with existing caste stratification on the basis of endogamy in the Muslim society in Cachar.

Copy Right, IJAR, 2018,. All rights reserved.
\end{abstract}

\section{Introduction:-}

Geographical Description:

Our present study centred round two district of Barak valley of southern Assam, i.e, Cachar and Hailakandi, eastwhile Cachar district of Assam, together with Karimganj District (A sub-division of the district of Cachar during post independence period and presently a district of Assam) formed Barak Valley. It was a part of greater Surma Valley, "geographically, historically and ethnically an extension of Gangatic Bengal."1 The area is bounded by the hills of North Cachar district of Assam, the Jaintia hills of Meghalaya in the north, by Manipur in the east, by the Hills of Mizoram in the south and Tripura and Shylhet District of Bangladesh in the west. The river Barak flowing across the land along with its many tributaries thereby formed the alluvial plain. Its unhealthy climate and frequent raids by the hill tribes resulted in the scanty human settlement during pre-colonial period. The fertile tract watered by the hilly rivers constitutes most suitable plain for agricultural activities while the rivers and large numbers of water bodies were abundant with palatable fish. This ecological background of the region remained as the main 
source attractions of large scale immigrants from Bengal, Shylhet being the nearest. The ethnic boundary of Barak Valley remained persistence because of its geographical feature, the hill people habitual in slash and burn cultivation did not come to the plain while the Bengalees, skilled in wet rice cultivation and fishing did not moved to the elevated tract of the neighbouring hills. Absence of any natural barrier towards Bengal allowed the large scale wave of migration of people from Bengal in general and Shylhet district in particular, who later settled in the valley during the Pre-British and British period. The Bengalees, both Hindus and Muslims comprise vast majority of the population of Barak Valley.

\section{Historical Development:}

The area of 'Barak valley' was known to the 'Banglee' as Kachar meaning 'a streach of land on the foot of, mountain. ${ }^{2}$ It was colonised by the Aryans during early period of History and formed the parts of Gauda, Vanga and Samatata later. In $13^{\text {th }}$ century, it was ruled by the Tepperahs and subsequently annexed to Tripura by the beginning of $16^{\text {th }}$ century. In 1562, it became a Koch principality. Later theDimachas established their kingdom in kachar. They ruled Kacahr till the British annexed the Kingdom after the death of last Kachari king GobindaCandra in the year 1830 .

\section{Social Development:}

Banglaee people both Hindus and the Muslims, speaking a local Bangalee dialect called Shylheti are majority of the people residing in Barak Valley during the Pre-British and British period. They migrated to this land from neighbouring district of Bengal. As a result, they brought with them many aspects of the social structure which was prevalent in the then Bengal, nearest being Shylhet. Therefore the Bengaleesociety in Barak Valley represents a replica of Bengalee society of Shylhet district of East Bengal. The Bengalee migrants settled in newly developed agricultural areas. "The early settlers were all peasants." 3 Along with the cultivators, the fishing and hunting communities like Kaibaerta, Namasudra, Patini and Muslim Fisherman (Mahimal) also migrated to this valley, followed by other occupational castes. They were encouraged by pre-colonial as well as colonial rulers with the basic objective of enhancement of revenue as the territory yielded very little income for the state. Even the trends of migration continued throughout the British period. There was no natural barrier between Cachar plain and Shylhet. The social boundary of Shylhet was thus, expanded as a uninterrupted historical process throughout the Cachar plain where land was suitable for cultivation. Therefore any systematic investigation of the Bengalee society of Cachar deserves detailed examination of the social structure of Shylhet district of Bengal.

\section{Social Structure among Muslims of Shylhet during the Pre-British period:}

The east-while Shylhet district of east Bengal at present comprises greater Shylhet division of Bangladesh, including Shylhet, Habijanjo, Sunamganjo and Moulavi Bazar and Karimganjo district of Assam. "During the Pre-British period, it was inhabited by the Hindus, Muslims, Brahmmins, Christians and Animistic, other than tribes, all the inhabitants were Bengalees." "The Muslim population in Bengal and Shylhet in particular, increased since the Muslim occupation of Shylhet, migration of small numbers of Muslims from north India, mass conversion to Islam by the downtrodden Hindu castes and last, not the least practice of widow remarriage and absence ill assorted marriage among Muslims unlike Hindus. ${ }^{5}$

As in case of rest of India, empirical studies confirm the presence of well precise social stratification among Muslims on the basis of descent, occupation, endogamy and social commensality. Bengal and Shylhet in particular was of no exception to this social phenomenon. As in the rest of India, the Muslim society in Shylhet was characterised by the existence of two broad social classes, the Ashrafs and Ajlafs. The Ashrafs or elite class claimed their foreign descent like Shaikh, Sayed, Mughal and Pathan and converts from high caste Hindus formed the nobility. "The ashrafs belonged to the dominant political elites." 6 The Ajlafs comprises converts from low caste Hindus and various occupational castes such as Mahimal ( Muslim Fishermen), Khiran (Tenant farmers), Patikar ( mat or pati makers), Mirshikar ( hunters of birds),Hajjam (Barber), Khalia (Tanner), Bajunia (Musiscian or Drum beater sometimes called Dhulia) and Ghulam (slaves or servants). They were indigenous converts mainly recruited from various occupational castes which were looked down upon as low by the Ashraf Muslims. "In some places a third class, called Arzals or 'lowest of all' is added. In the context of Shylhet, they were called Atrap. It consists of the very lowest castes, such as the Halalkhor, Lalbegi, Abdal and Bediya, with whom no other Muhammadan would associate, and who are forbidden to enter the Mosque or to use public burial ground." 7 There were well defined social hierarchies carefully maintained through strict role of endogamy, commensality and social intercourse. 
Large scale conversion to Islam in Shylhet took place after coming of famous Sufi saint Shaikh Shah Jalal who came with to Shylhet along with 360 disciples ( Awliya). The Hindus, especially the low castes embraced Islam inspired by the Islamic message of social equality and brotherhood and with the objective of liberation from age old bondage of social slavery. But even after the conversion, their social, economic and political environment remained all the same. They remained tied with their hereditary occupation. Empirical studies confirms that low caste converts largely adopting such occupation which were significantly perused by the low caste Hindus and were looked down upon by the 'Ashrafs' Muslims as demeaning. "The Ashrafs comprises Shaikhs, Sayeds, Mughal and Pathans mainly the Muslims claimed their decent from foreign origin."9 But historical and sociological studies provide contrary evidences regarding the foreign origin of all those claiming foreign descent. The Sayed were the descendent of Prophet Muhammad through his daughter Fatema and Hajart Ali, but in India, many indigenous converts also claimed their descent from foreign origin due to its social and political realities, people invented their foreign ancestry.

Sometimes converted Muslims were bestowed with the title Shaikh as a mark of honour, and sometimes the converts tends to identify themselves with the person who converted them. "In the proper sense of the words, Shaikh should be Arabs and Saids, descendents of Ali, includes a great numbers of persons of purely local origin."10. Therefore, many converted Muslims converted by Shaikh Shah Jalal tend to identify themselves as Shaikh. In the context of Shylhet, a section of Mahimals, converts from low caste Hindu, Kaibertas, Patni, Namasudra, claimed to be Shaikh. ${ }^{11}$ The Mirshikar and Khiran also claimed themselves to beShaikh. Inspite of this kind of social experimentation, the low caste Muslims like Mahimals, Kiran, Patikars, Mirshikars, Bajuniaand Hajjam remained despicable and could not acomplish social mobility, their class and status and remained as Ajlafs. This was due to the practice of the strict role of endogamy. The inter caste marriage was, of course not prohibited by any elaborate role of law, but strongly frown upon and sometimes, transgressors were abandoned by their relatives. Thus, there was no inter-caste marriage between so called Ashrafs and so called Ajlafs." The 'Ashrafs' comprises single endogamous community." 12 The occupational castes like Mahimals, Kiran, Patikar and Hajjam comprises separate endogamous community for each of them. Marion Smith provided a description of the social classes of village Alankar (olonkari), about 7 miles south-west of the town of Sylhet, East Bengal (now Bangladesh). She says that there are seven villages around Alankar which form a unit. There exist eight groups among the Muslims of the seven villages, viz. Soyod, Choudry, Sekh, Mogul, Majumder, Fartan (Pathan), Gulam and Maimul. The first six of these groups consists of persons who are primarily land owners and who engage in trade. The last two groups seem to be distinguished from the first six by occupation and by practical endogamy. Gulams who are wealthy and own much land still do not associate freely with other Muslims outside the Mosques, and because they go barefoot in public places, they may be always recognized. Maimul are net workers and fishermen. ${ }^{13}$

The Mahimal, including Kiran, Patikar, Hajjam, Bajunia and so called Ghulam remained at the bottom of social structure due to their low occupational status. "The occupation of a fisherman is lower throughout Bangladesh." 14 "Islamization as a process of social change has not led to the integration of the community with other Muslim social groups of the region into an Islamic 'Ummah' Rather Mahimals exists as a separate social category even among their co-religionist. Social mobility through Islamization also could not become a mass phenomenon among them."15 The existing social stratification among Muslims was further proliferated as result of emergence of political and landed aristocracy during the Pre-British and British period.

After the death of Shaikh Shah Jalal, Shylhet was included in the kingdom of Bengal and put in charge of a Nawab. During the time of Akbar, it passed with the rest of Bengal into the hands of Mughal Emperors and from that time, it was ruled by Amils (locally known as Nawab), subordinate to the Nawab of Dhaka. Shylhet was classed as one of the Sarkars of Bengal with 8 Mahals. In 1727, MurshidKuli Khan (1705-1727) introduced a new policy known as 'JamaKamaliTumar' (revised revenue details) and Shylhet was included within 13 Chaklas to which whole Bengal was divided. Six years after, this revenue policy was made permanant features of Muslim land revenue administration. During the reign of NawabSujauddin, who divided Bengal into 25 'Zamindaries', Shylhet was classed as one of such 'Zamindaries', having 36 parganas. During the rule of the Nawab of Bengal, Shylhet was administered like other Sarkars or Chaklas. The revenue officer of Shylhet was Diwan. Diwan was assisted byKanungoes- theMazumderKanungoes, helped the revenue collection.

During the reign of Akbar, those who were entrusted with revenue collection, were given the title of Choudhury, at the times of later rulers, the title was not confined to the revenue collection only. It also came to be conferred to the 
land holders and then they became hereditary. During the Muslim rule, those Choudhuries along with the Rais (owner of 500 horsemen) and RaiBahadur (Owner of 200 horsemen) was stable element of administration.

In March, 1793, 'DahasalaBandobasta' or permanent settlement was introduced in Bengal. In Shylhet, generally spaeaking, the Choudhuries were principal landlords and the landholders paying a revenue of Rs. 500/- were regarded as Zaminders and those paying less than Rs.50/- were considered as Talukdars or Tapadars. ${ }^{16}$.The titles like Choudhury and TalukdarandTapadar are largely used by the upper strata of the Musllim society in Karimganjo district of Assam which was earlier a part of Shylhet and under Muslim rule during the pre-colonial period. But Cachar was never under any Muslim ruler and upper strata of the society commonly used titles like Choudhury, Barbhuiya( BaroBhuiya) Laskar, Mazumder, Barlaskar (BaroLaskar) etc.

\section{Muslim Landed Aristocracy in Cachar}

"The Bengalee Muslim Society as a whole and regional Muslim society in Barak valley in Particular emerged during medieval period as a result of migration of a small numbers of Muslims from northern India and largely as a result of mass conversion of local people perusing Hindu, Buddhist and animistic beliefs and practices." 17 Bengali Muslims of Barak Valley are basically Muslims migrated from Shylhet. There was conversion to Islam by local people particularly under the influence of many Sufi saints. The Presence of good numbers of old holy Shrines in most parts of Barak Valley is a testimony to this fact. It is also presumed by scholars that many soldiers who accompanied invading armies settled in Cachar and mixed up with local population. Barak Valley was a part and parcel of Surma Valley during the period of preaching of Islam.

The land revenue system of the early Kachari rulers was based on Khel system. "The early settlers all were peasants. They organised in groups and then proceed beyond settled areas to occupy a fellow tract of size that would enough for subsistence of group. They set up boundary, reclaim the tract collectively, started cultivation and established the village in a portion of the area reclaimed by the group. The area was known as Khel, Khel was a an agricultural guild, collectively managed by habitant, They elected from their rank a headman called 'Mukhter' who managed affairs of the khel. Every Khel had a 'Mukhthar' and those Mukhthars were locally known as Bhuiya or Laskar." "The Khel formed the agricultural community in Cachar, but its members were not connected by any ties of kindred, caste, nationality or creed. From the first, Muslamans and Hindus are found side by side in same Khel. In course of time, as the numbers of Khel increased," ${ }^{19}$ all the Khels in a particular locality formed a union, called Raj became ten to cover between themselves the entire tract of Cachar plain come to be known as land of Desh Raj. The Mukhtars of the constituents Khel elected Raj Mukhtars with various titiles likeChoudhury, Majumder, Barlaskar, Barbhuiya, Major Bhuiya, ChotaBhuiyaetc all according to the status and importance of the unit. The Choudhuries or the head of the Khel got two andhalof land free, Mojumders, one half, theLaskars, one fourth of thehal, Barbhuiya and MazarBhuiya six kiyars. These titles were still largely used by the Muslims of Cachar.

From the history of Cachar, we came to know that, in the early part of nineteenth century, Raja Krishna Chandra of Cachar while returning from pilgrimage through Shylhet came to know that some people were bearing titles like 'Choudhury', 'Mazumder'etc at the end of their names. His royal treasury was running in deficit. With objective of filling up empty treasury, he decided to distribute suitable titles to his subjects both Hindus as well as Muslims in exchange with a payment. On his return to capital, he started the process of distributing titles, but he could not complete the process and died a premature death in 1813 A.D.

"Gobinda Chandra on ascending throne transferred his capital from Khaspur to Dudhpatil. Then he accomplished the process proposed title distribution of Raja Krishna Chandra. In 21Srabana, 1739 Saka era, (1817 A.D.) task of title distribution was started. In this unusual way, huge amount of money was deposited to royal treasury. The Brahmin, Kayastha, Hidla, Patni, Nath subjects both Hindus and Muslims received four types of title i,e, Choudhury, Mozumder, Laskar, Bhuiya. The value of these titles were fixed at 100./-, 50/-, 25/- and 15/- respectively. They were issued afarman or deed with mentioning the names of those who received the titles. Then for two years many people had received titles. They were entitled to enjoy various privileges as per their titles." ${ }^{20}$

After annexation of Cachar, the colonial authorities were not in favour to interfere with existing system of land revenue collection from the point of administrative difficulty as well as not to injure the sentiments of the people. G Verner, the then officiating superintendent of Cachar, in a letter dated $11^{\text {th }}$ March, 1850 to $\mathrm{R} H$ Mython, the officiating commissioner of Dhaka Division, expressed his willingness to retain these hereditary titles used by the people of Cahcar. ${ }^{21}$ 
"Initially, the clung of the land its representatives, but curiously enough, in course of time they became transferable at fixed prices. In the early days of company, the title of choudhury fetched Rs. 100 that of MazumderRs. 75. LaskarRs. 60, Bara BhuiyaRs. 50, Major Bhuiya and ChotaBhuiyaRs. 40. The title became hereditary and by degree of unions began to separate into classes." ${ }^{22}$ Some of these titles were used by the Muslims of Cachar and still in use by the descendent of those whose forefathers obtained titles either from the pre-colonial or colonial rulers, but large scale use of these titles started later and became a common practice among Muslims of Cachar except a few occupational castes. Actually, Bhuiyas having three categories like BaroBhuiya, ChotaBhuiya, MazorBhuiya and likewise ChotaLaskar, MazorLaskar and BaroLaskar. Out of that, now only Bara Bhuiya, LaskarBaroLaskarand Mazumder are found to be largely used by the elite class of the Muslims. It is observed that almost all Muslims except a few occupational castes like Mahimals, Kirans, Patikars, Bajuias,,Hajjams and Ghulams used these titles at the end of their names.

It is observed through a field work in two villages in Cachar district that many people who are using these titles are newly adopted at a considerable later period whose forefathers never had any such titles. It was due to the fact that tradition of writing titles with the names was copied from their neighbours with the objective of raising their position in social scale with a process of social mobility by common farmers and intermediate class of people. The subsequent census records that contained the name of citizens and the old land records indicate the same. Besides, villages after villages from one corner to another in present Cachar and Hailakandi district, the people having different titles with their names, cannot be statistically ascertained, all being the descendents of landed elites. These titles used by the Muslims in Cachar became a basis of social class formation and emergence of stratification in Muslim society in Cachar.

"The highest status in the regional society is occupied by the Syeds because of their descent from Prophet's family. The next position is occupied by the Choudhuries because of their supposed purity of blood and economic power due to land ownership. The Mazumdars, Talukdars, Laskars and Bhuiyas also share the second position in the hierarchy along with the Choudhuries. There is no bar in inter-marriages among these groups. They resemble to the ' $d$ wiza' or twice-born group of the Hindus and known as ashrafs. The kirans, various occupational groups and Mahimals constitute the lower strata." 23 "The upward social mobility was experienced by group like Kirans, whose occupation was agriculture and no social stigma was added to their occupation.

"It appeared from our observation that for Kirans it was is easier to move up in the hierarchy because of their nonassociation with a particular traditional occupation. Acquisition of more land leads to upward movement for a Kiran followed by the adoption of titles like Choudhury, Laskar or Bhuiya. Moreover, unlike other occupational groups of Hajams and Mahimals there has been absence of a sense of community feeling among the Kirans"24

The people who bear titles like Choudhury, Barbhuiya ( BaroBhuiya), Mazharbhuiya (MazorBhuiya), Barlaskar, (BaroLaskar), Laskar and Mazumder are considered as 'Ashraf' or higher strata of the society while many occupational castes like Mahimals, Kiran, Patikars, Hajjam, Bajunia ( Dhulia) and Ghulam are considered as Ajlaf or lower strata of the society. There was a wave of social mobility by the people of other occupation or people of intermediate class, especially the agriculturalist, who started adoptimg various titles used by landed class and merged with them in social standing. They could achieve it because of the fact that no stigma was associated with the profession of cultivator and it is a common profession pursued by all class of people. The occupational caste likeMahimal (Muslim Fisherman), Patikar (mat artisan), Hajjam (berbar), Khalia (tanner), Dhulia( Musician or Drum player) and Ghulam (slave or servant) could not experience this upward social mobility because of their association with stigmatized occupation.

The class formation in Muslim society in Cachar on the basis of landed aristocracy became the basis of caste stratification. Many visible attributes of caste are found in Muslim society of Barak Valley, the most significant one being elaborate practice of endogamy. The people bearing these titles comprise single endogamous community while occupational castes like Mahimals, Kiran, Patikar, Bajunia andHajjam comprise separate endogamous communities. 


\section{Conclusion:-}

Therefore on the basis of above discussion, it is concluded that the emergence of landed aristocracy in Muslim society in Cachar proliferated the existing Muslim social stratification leading to the large scale social mobility and 'Ashrafization' of Muslim social order while the occupational caste like the Mahimals, Kiran, Patikar, Hajjam, Bajunia etc remained at the bottom of the social hierarchy who could not experience social mobility because of their association with particular occupation. This was confirmed by the elaborate practice of endogamy and many other objective attributes of caste leading to the continuation of Caste Stratification along with newly emerged class stratification among the Muslims in Cacahr district.

\section{Notesand References:-}

1. S K Chaube, quoted in JB Bhattacharjee : Cachar Under the British Rule in North East India, Radiant Publisher, New Delhi, 1977, p-20

2. A. C. Chaudhury : SrihatterItibritta, Purbangsa (in Bengali) UtsaPrakashan, Dhaka, 2004, p-520

3. . J B Bhattacharjee : Khel Roots of agricultural commonwealth in Cachar, Journal of Assam University, Silchar, Vol-I, No. I, January, 1996, p-1

4. A. C. Chaudhury, Ibid, p-83

5. C.J. O'Donnell as quoted in H K S Arefeen : The Hindu Caste Model and Muslim system of Stratification in Bangladesh, Unpublished Thesis, Department of Anthropology, Memorial University, Newfoundland, 1975, p-48

6. YoginderSikand : Islam, Caste and Dalit-Muslim Relation in India, Global Media Publication, New Delhi, 2004, p- 20

7. Census Report, Bengal, 1901 as quoted in H HRisley : The People of India, Second Edition, (edited by William Crooke), MunshiramManoharlal, New Delhi, 1991

8. "The vacation of musician, delver, washer man, fisherman and indigo-dyer, formerly pursued by out caste Hindus, were subsequently adopted by the poor Mussalman or convert to that faith," James Wise : Notes on the Races, Castes and Trades in Bengal, Harrisons and Sons, London, 1883, p-35

9. YoginderSikand : Ibid, p- 21

10. Gait quoted by HKS Arefeen : Ibid, , p-51

11. During census, many Mahimals has registered themselves as Shaikh, A. C. Chaudhury, Ibid, p- 93

12. Harun Akbar : AbhijatayaeShylhetySamaj (in Bengali) JalaabadLokSahityaParishad, Shylhet, Bangladesh, 1999, P- 29

13. Marion Smith, as quoted in A. K. Nazmul Karim: Changing Society in India and Pakistan, Oxford University Press, Pakistan, 1956, pp- 156-158

14. Arefeen, H.K.S. Ibid, p-69

15. HumayunBokth : Ecology, Economy and social Transformation among merginalised communities : A Study of Muslim Fisherman of Barak Valley, Assam, IOSR Journal of Humanities And Social Sciences, Vol- 19, Issue12, Ver, 1(Dec-2014) p -57)

16. A. C. Chaudhury : Ibid, p-80

17. Humayun Bokth : A Sociological study of Muslim Fishing Community of Barak Valley, Unpublished Ph.D. Thesis, Department of Sociology, Guwahati University, Guwahati. 2014, p-27

18. J B Bhattacharjee :1996, p-1

19. WW Hunter: Statistical Accounts of Assam, Vol-II, Trubner\& Company, London, 1879, pp -395-96.

20. U C Guha : KacharerItibtitta, ( in Bengali) SopanPrakashan, Kolkata, 2012, pp- 161-162

21. Ali Haider Laskar :A History of the Muslims and the Barak Valley, PrithibiPrakashan, Guwahati, 2013, p- 1556.

22. A.S.R file No. 606 of 1872: CR; No, 36 of 1850, as quoted in J.B. Bhattacharrya: 1977, p-76

23. HumayunBokth : 2014, Ibid, p-44

24. HumayunBokth : 2014, Ibid, pp-44-45 